\title{
Deirochelys reticularia (Latreille 1801) - Chicken Turtle
}

\author{
Kurt A. Buhlmann ${ }^{1}$, J. Whitfield Gibbons ${ }^{1}$, and Dale R. Jackson ${ }^{2}$ \\ ${ }^{1}$ University of Georgia, Savannah River Ecology Lab, Drawer E, Aiken, South Carolina 29802 USA \\ [kbuhlmann@earthlink.net; wgibbons@uga.edu]; \\ ${ }^{2}$ Florida Natural Areas Inventory, Florida State University, \\ 1018 Thomasville Road, Suite 200-C, Tallahassee, Florida 32303 USA [djackson@fnai.org]
}

Summary. - The chicken turtle, Deirochelys reticularia (Family Emydidae), is a semi-aquatic turtle inhabiting temporary and permanent freshwater and adjacent terrestrial habitats throughout much of the Atlantic and Gulf Coastal Plains of the USA. Three subspecies are recognized: $D$. $r$. reticularia, D. r. chrysea, and D. r. miaria. Local population sizes are generally small; as such, chicken turtles are seldom the dominant species of turtle at any site. The species differs from most other North American turtles in having a nesting season that extends from fall to spring, followed by a long incubation period. Threats to this species come from the disruption, destruction, or isolation of freshwater wetlands, including small or temporary ones, and the elimination or alteration of surrounding terrestrial habitats. The species is not currently considered globally endangered, though some peripheral populations (e.g., those in Missouri and Virginia) are listed as locally endangered.

Distribution. - USA. The range extends from North Carolina, through peninsular Florida, to eastern Texas, primarily in the coastal plain, and includes populations in Virginia and Oklahoma through Arkansas to southeastern Missouri.

Synonymy. - Testudo reticularia Latreille 1801, Emys reticularia, Clemmys reticularia, Deirochelys reticularia, Testudo reticulata Daudin 1801, Emys reticulata, Terrapene reticulata, Clemmys reticulata, Deirochelys reticulata, Chrysemys reticulata.

SubSPECIES. - Three recognized: Deirochelys reticularia reticularia (Eastern Chicken Turtle), Deirochelys reticularia chrysea Schwartz 1956 (Florida Chicken Turtle), and Deirochelys reticularia miaria Schwartz 1956 (Western Chicken Turtle).

STATUS. - IUCN 2007 Red List: Not Listed (= Least Concern, LR/lc) (assessed 1996, needs updating); CITES: Not Listed; US ESA: Not Listed.

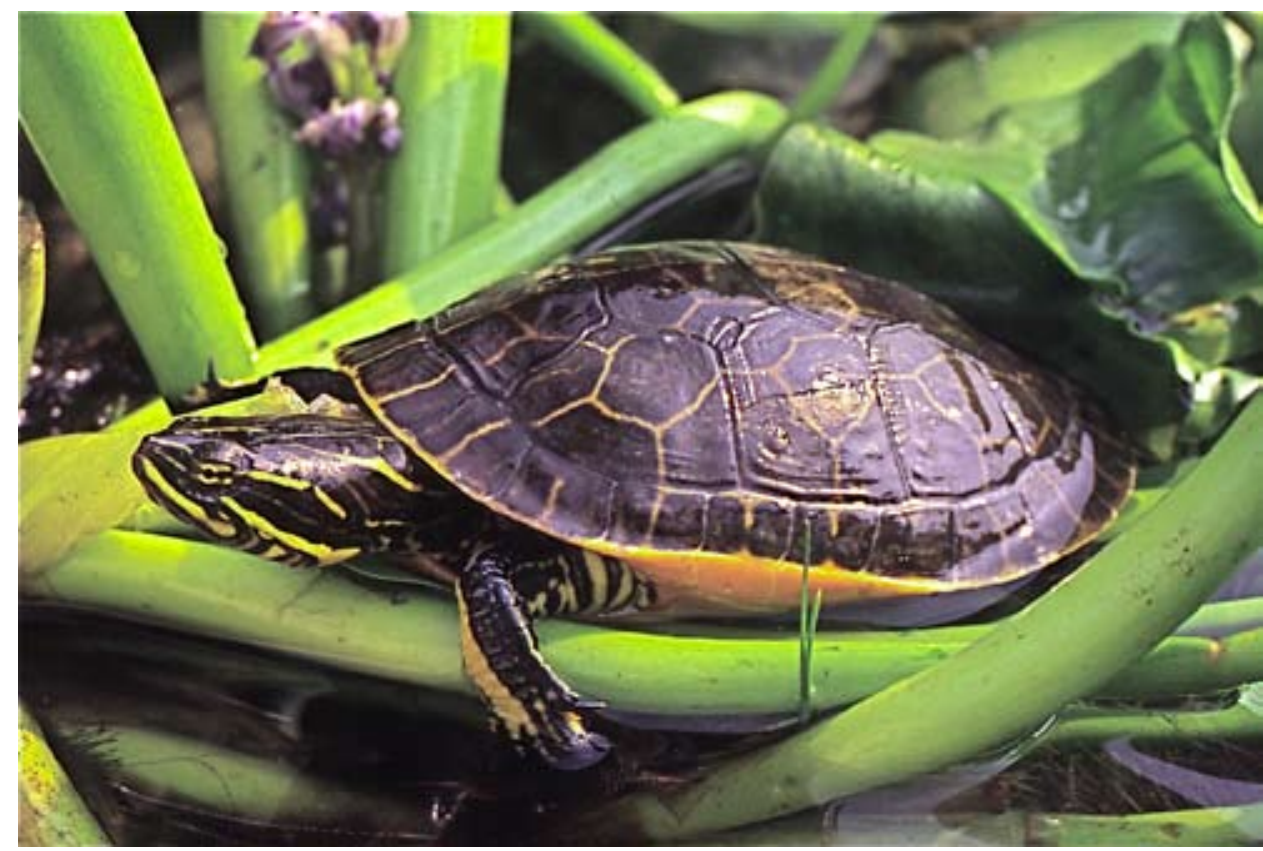

Figure 1. Adult Deirochelys reticularia from central Florida. Photo by Kurt A. Buhlmann. 


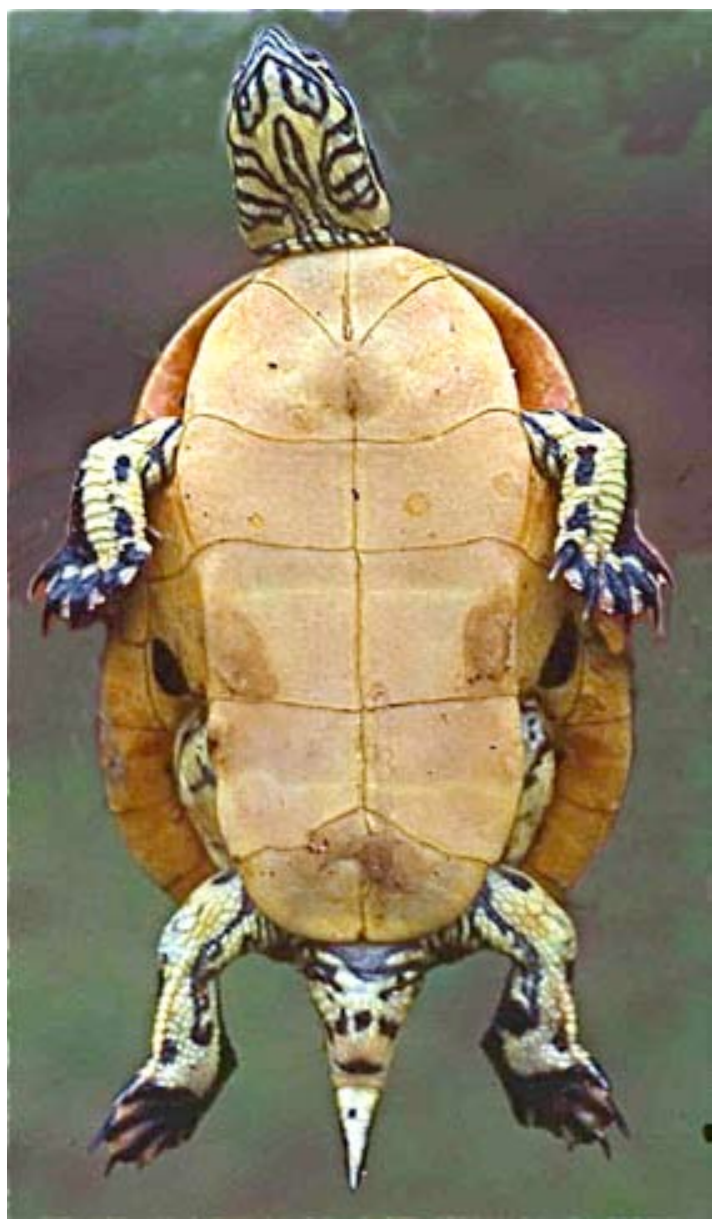

Figure 2. Adult Deirochelys reticularia from the Savannah River Site, Aiken County, South Carolina. Photo by Kurt A. Buhlmann.

Taxonomy. - This species was originally described as Testudo reticularia by Latreille in 1801 based on a specimen presumed to be from the vicinity of Charleston, South Carolina. During the next century, the species was assigned to various genera (Emys [Schweigger 1814], Terrapene [Bonaparte 1831], Clemmys [Strauch 1862], and Chrysemys [Cope 1875]). Moreover, it was misspelled Dirochelys by Baur (1890), Hirochelys by Beyer (1900), and Dierochelys by Loding (1922). The original spelling (Deirochelys) by Agassiz (1857) and used by Gray (1870) is the correct usage. Schwartz (1956) separated the speciesintothreesubspecies (D.r.reticularia, $D . r$. chrysea, and D.r. miaria), which are still recognized.

The chicken turtle's apparently monophyletic evolution as a genus, since at least the early Miocene (Jackson 1978), is unusual among the many genera of turtles occurring in the southeastern United States. Although many early authors suggested a close relationship between Deirochelys and the genus Emydoidea, based principally on their similarly long necks, most recent turtle systematists have rejected this hypothesis (Jackson 1978; Seidel and Adkins 1989) and view the two as convergent.

Description. - Hatchling chicken turtles average about $30 \mathrm{~mm}$ in carapace length (CL). Males reach maturity at plastron lengths (PL) of 75-80 mm; whereas, mature females are generally more than $140 \mathrm{~mm}$ PL (Gibbons 1969; Gib-

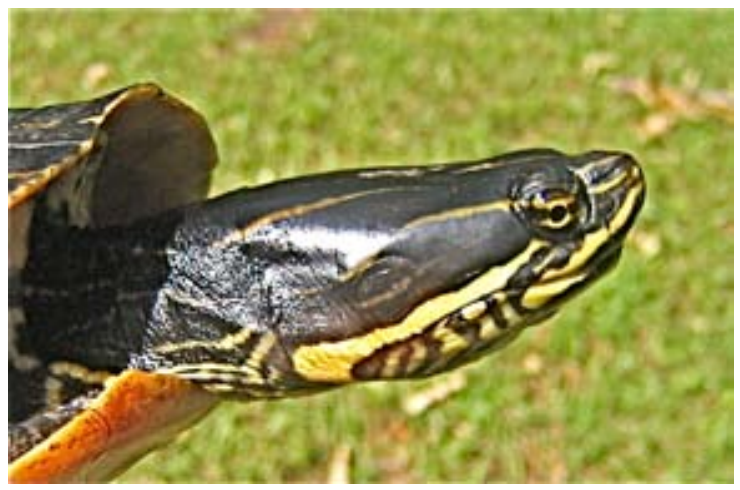

Figure 3. Adult Deirochelys reticularia from the Savannah River Site, Aiken County, South Carolina. Photo by Kurt A. Buhlmann.

bons and Greene 1978; Jackson 1988). The maximum size reported for the species is approximately $250 \mathrm{~mm}$ CL for females and 157 for males. Sexual dimorphism is evident in all populations, with females reaching larger sizes (Gibbons and Lovich 1990) and males having longer, thicker tails. Unlikemany other emydid turtles with which they co-exist, chicken turtles exhibit no sexual dimorphism in length of the foreclaws.

The carapace may be brown, tan, or olive. A reticulate pattern of light yellow lines is often visible. The plastron is usually plain yellow. Patterning on the bridge varies among individuals and may be expressed as a black bar, one or two spots, or no markings. The brown to olive skin has yellowish stripes on the head and legs, with one on each foreleg usually being much broader. Vertical stripes are visible on the proximal posterior portion of the hindlegs.
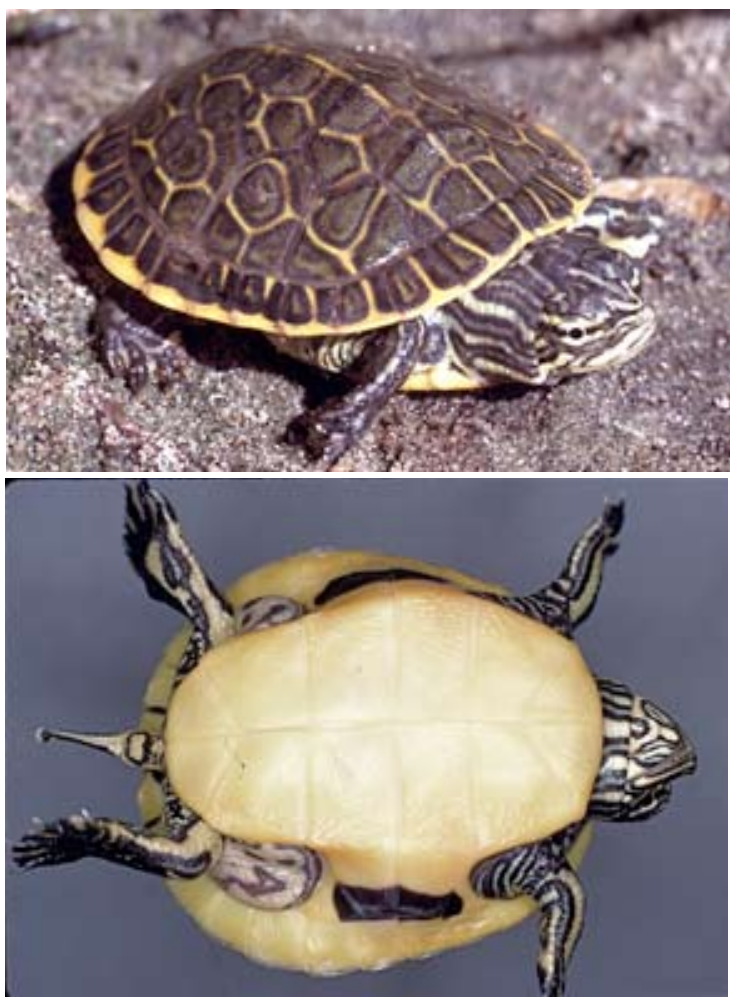

Figure 4. Hatchling Deirochelys reticularia. Top: from Pinellas County, Florida; photo by George Heinrich. Bottom: from Dixie County, Florida; photo by Michael A. Ewert. 


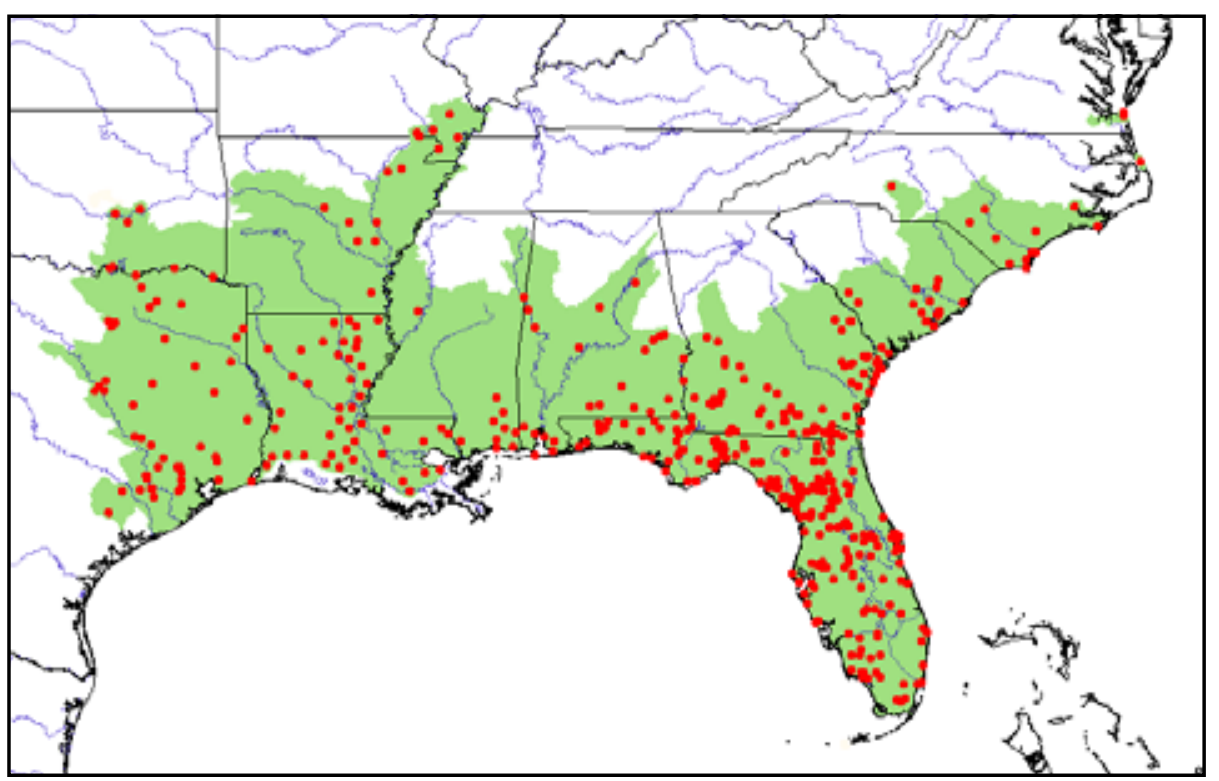

Figure 5. Distribution of Deirochelys reticularia in southeastern USA. Red points = museum and literature occurrence records based on published records plus more recent and authors' data; green shading = projected distribution based on GIS-defined hydrologic unit compartments (HUCs) constructed around verified localities and then adding HUCs that connect known point localities in the same watershed or physiographic region, and similar habitats and elevations as verified HUCs (Buhlmann et al., unpubl. data), and adjusted based on authors' data.

The carapace is longer than wide and is widest toward the rear, appearing somewhat pear-shaped from above. The edges of all marginals are smooth. Fine, longitudinal ridges occur over much of the surface of the carapace. The vertebrals are wider than long, and the plastral formula is abd $>$ an $>$ gul $>$ fem $>$ hum $><$ pect (Ernst and Barbour 1989, but see Lovich and Ernst 1989). The neck is extremely long; the head and neck extended being approximately as long as the plastron.

Distribution. - The contiguous range of $D$.reticularia extends from middle North Carolina, through peninsular Florida, to eastern Texas, primarily in the coastal plain. Populations occur in southeastern Oklahoma, through the southern half of Arkansas, and up the Mississippi River valley to southeastern Missouri. Isolated populations are found on the Outer Banks of North Carolina (Braswell 1988) and in southeastern Virginia (Mitchell and Buhlmann 1991).

Deirochelys $r$. chrysea ranges throughout peninsular Florida; whereas, D. r. miaria is found west of the Mississippi River, and D. r. reticularia occupies the remainder of the range from Louisiana, east of the Mississippi River, to Virginia and northern Florida.

Habitat and Ecology. - Deirochelys reticularia is an aquatic species, but individuals of both sexes frequently travel overland for purposes other than egg-laying (Bennett et al. 1970; Gibbons 1970; Buhlmann 1995). Although the species appears to be principally diurnal, Buhlmann (1998) observed aquatic nocturnal activity during March in South Carolina. Both sexes of $D$.reticularia in Florida were most active during morning hours and early evening afterdark(Ewert 2006). Nocturnal terrestrial activity has not been reported.

The species is a carnivorous, aquatic feeder specializing on arthropod prey, especially crayfish and aquatic insects (Jackson 1996). Dragonfly and damselfly nymphs were the most abundantly consumed food items in a Carolina bay in South Carolina during the summer months (Demuth and Buhlmann 1997). The long neck allows the chicken turtle to strike rapidly to capture prey items that are capable of quick escape. Small fishes and fishing spiders may be taken alive in this manner. At least some scavenging of dead fish and other animals is likely. Terrestrial insects and adult dragonflies, presumably captured after they have fallen into the water, are also included in the diet.

The general reproductive cycle of the chicken turtle is distinctive from all other species of North American turtles. Deirochelys reticularia has not been reported to nest during the late spring and summer months to which most other North American turtles confine their nesting activities. In Florida, Carr (1952) reported chicken turtles nesting from September to January, and Jackson (1988) observed nesting from September into March. The majority of nesting by South Carolina females has been observed in late August to November and from February into April, but some nesting has been documented in December and January.

Clutch sizes of chicken turtles have been reported as high as $12($ mean $=8)$ in South Carolina (Gibbons et al . 1982) and $19($ mean $=9.5)$ in Florida (Jackson 1988). Two clutches are frequently laid within a year in South Carolina; whereas, as many as four clutches per year have been reported from Florida (Buhlmann 1998; Ewert 2006). Retention of hard-shelled eggs from autumn to spring has been documented in South Carolina. The ability to retain eggs presumably prevents the loss of that reproductive effort when an early cold period truncates the autumn nesting season (Buhlmann et al. 1995).

The eggs are parchment-shelled with mean dimensions of $36.0 \times 22.0 \mathrm{~mm}$ and a mean wet mass of $10.6 \mathrm{~g}$ for eggs laid in the fall in South Carolina, and 34.4 x $20.4 \mathrm{~mm}$ and 
$8.5 \mathrm{~g}$ for those laid in the spring (Congdon et al. 1983; Congdon and Gibbons 1985). Mean egg length for females from Florida was $36.5 \mathrm{~mm}$, and mean egg mass was $10.7 \mathrm{~g}$ (Jackson 1988).

The incubation period is temperature-dependent and can be extended by exposure to low temperature, with little or no development occurring below $22^{\circ} \mathrm{C}$. Jackson (1988) reported incubation periods of $78-88$ days at ca. $28-29^{\circ} \mathrm{C}$ for eggs from Florida. However, he has extended the time to hatching up to 194 days in the laboratory by first holding the eggs at low temperatures $\left(4-22^{\circ} \mathrm{C}\right)$ for as long as 116 days prior to warming them to $28^{\circ} \mathrm{C}$ (Jackson, unpubl. data). Such a regimen more closely mimics incubation in the wild, where eggs laid in the fall or winter may remain dormant for months prior to encountering soil temperatures sufficiently high to support continued development. Buhlmann (1998) hatched eggs that were first chilled for 30 days at $15^{\circ} \mathrm{C}$ and subsequently incubated for 75 days at $28^{\circ} \mathrm{C}$; eggs from the same clutch, incubated without chilling, failed to hatch. In natural situations in South Carolina, most hatchling chicken turtles have been observed to emerge during spring (Gibbons and Nelson 1978), although some hatchlings have been found entering aquatic habitats in August.

Chicken turtles are reported to have temperaturedependent sex determination, with a higher proportion of males being produced at $25^{\circ} \mathrm{C}$ and females at $30^{\circ} \mathrm{C}$ (Ewert and Nelson 1991). Adult sex ratios in thoroughly studied populations have deviated from $1: 1$, with a greater number of adult males than females being present in all instances (Gibbons 1990).

Growth rates of immature chicken turtles in South Carolina ranged from 25-44 mm per year (Gibbons 1969). Males were estimated to attain maturity between $75-80 \mathrm{~mm}$ in PL in the South Carolina population (Gibbons and Greene 1978), and less than $97 \mathrm{~mm}$ in Florida (Jackson 1988). The smallest females observed with eggs had a PL of $141 \mathrm{~mm}$ in South Carolina and $145 \mathrm{~mm}$ in Florida.

The highest population densities have been reported in Carolina bays in South Carolina, temporary wetland habitats in which the species is aquatic during part of the year (Gibbons 1969; Gibbons and Greene 1978; Congdon et al. 1986). Some populations that appear to be viable may contain fewer than 40 adults, and these sometimes occur in permanent lentic waters (J. Greene and Gibbons, unpubl. data).Population densities of 17.7 individuals/ha in a Carolina bay and 7.2 in a farm pond have been reported from South Carolina (Congdon et al. 1986).

In a four-year study at Dry Bay, a seasonal freshwater wetland on the Savannah River Site (SRS) in South Carolina, all male and juvenile Deirochelys were observed to exit from the aquatic habitat on a seasonal basis each year (Buhlmann, 1998; Buhlmann and Gibbons 2001). In contrast, some adult females used terrestrial refugia in association with nesting forays but typically not for long-term aestivation or hibernation (Buhlmann and Gibbons 2001). Males have been observed to remain in terrestrial refugia for more than six months in most years. However, in another study, where the aquatic habitat dried completely during a drought, females exited to the adjacent forest where they buried beneath leaf litter (Buhlmann 1995). As with males and juveniles, females can remain buried on land for several weeks or months. Chicken turtles have higher fat reserves than other sympatric species of turtles (Ewert et al. 2006), which facilitate long non-feeding periods of inactivity on land.

A life table has not been constructed for the chicken turtle, but survivorship information is available for some life stages. Minimal adult survivorship has been estimated under natural conditions in South Carolina, with some individuals living up to $15 \mathrm{yrs}$, and one more than 20, but not as long as other turtle species being studied (Gibbons 1987). Buhlmann (1998) noted that due to the lower survivorship patterns, most female chicken turtles reproduce for fewer than 10 breeding seasons. In the SRS study at Dry Bay, D. reticularia males and juveniles of both sexes left the aquatic habitat for terrestrial refugia from late summer through winter(Buhlmann 1998). Survivorship among these varied from $96 \%$ in each of the first two years to $62 \%$ in the third year (Buhlmann and Gibbons 2001). Survivorship for the remainder of each year in the aquatic habitat was 67,46 , and $40 \%$.

Population Status. - Because it is generally assumed that the chicken turtle is not particularly threatened, there have been no range-wide status surveys for this species. The species is considered rare and of conservation concern only in those states whose boundaries are peripheral to its range. Two states list the chicken turtle as locally Endangered: Missouri, where until 1995, no specimens had been reported since 1962 (Anderson 1965; Buhlmann and Johnson 1995) and Virginia, where a single relict, widely disjunct population is known (Buhlmann 1995). The species also appears to be extremely rare in Arkansas (M. Plummer, pers. comm.). Although relatively common and widespread elsewhere, the chicken turtle does not seem to be especially abundant in any part of its range. Although $D$. reticularia is generally a minor component of the turtle fauna at most localities, the species was the most abundant resident of eight species of freshwater turtles at Dry Bay, South Carolina (Buhlmann and Gibbons 2001). Throughout its range, the species virtually never appears in the large basking assemblages characteristic of many regionally sympatric emydids.

Threats to Survival. - Although data are lacking, the substantial loss of freshwater wetland habitats in the southeastern United States, chiefly from filling or draining for agriculture and development, certainly has caused a general decline in the populations of many native amphibians and reptiles, including the chicken turtle. Conversion of bottomland hardwood swamp forests to agriculture is thought to be responsible for the declines in Missouri and Arkansas. As one of the few reptiles typically using temporary wetlands, the chicken turtle may have suffered greater losses than most, as these habitats receive relatively little regulatory protection.

Chicken turtles also use surrounding upland habitats. All radiotagged turtles wintered on land during a study of the Virginia population (Buhlmann 1995). More than 50 
chicken turtles, predominantly juveniles and males, but also several females, wintered (September through March) 50-250 $\mathrm{m}$ from a Carolina bay in South Carolina (Buhlmann and Gibbons 2001). Most of these turtles chose an older live oak and pine forest, with fewer choosing an adjacent 5-year-old clearcut. Even the most stringent wetland protection laws do not protect more than $100 \mathrm{ft}(30.5 \mathrm{~m})$ of adjacent uplands (Burke and Gibbons 1995).

Consumption of chicken turtles by humans seems to be relatively infrequent and is not likely to be a substantial threat to the species. Likewise, the species is only a minor component of the pet trade (Enge 1991). Buhlmann (1998) observed introduced fire ants kill all emerging hatchlings from a single nest, and predation by this invasive species may be a significant source of additive hatchling mortality for chicken turtles, as well as other turtle species.

Conservation Measures Taken. - Other than designation of the chicken turtle as Endangered by Missouri and Virginia, there seems to be little formal protection directed at the species. In Virginia, the Division of Natural Heritage (DNH) has made management recommendations for protection of the one known population (DNH, unpubl. data). At least some states (e.g.,Arkansas, Louisiana, North Carolina) within the range of Deirochelys have rules or statutes that regulate (but do not prohibit) the taking, especially for subsequent sale, of all native amphibians and reptiles, including the chicken turtle.Some states, e.g., Georgia, North Carolina, Oklahoma, and Texas, also regulate the taking of native turtles. The species is not listed on the IUCN Red List, on CITES appendices, or by the US Endangered Species Act.

The most effective conservation approach for chicken turtles is the protection of freshwater wetlands and surrounding upland habitats. Fortunately, the Federal and several state governments, as well as nonprofit organizations such as The Nature Conservancy, have secured protection for many thousands of acres of habitat occupied by this species throughout its range, although the intended focus of such protection was usually directed at birds, rare plants, or a water supply. Chicken turtles are known to occur in at least the following protected areas: Apalachicola and Ocala National Forests (both in Florida), Okefenokee National Wildlife Reserve (on the Georgia-Florida border), Big Cane Conservation Area (Missouri), Seashore State Park (Virginia), Nags Head Woods Nature Conservancy Preserve (North Carolina), and Savannah River Site (South Carolina).

Conservation Measures Proposed. - Stronger measures are needed in all states to protect freshwater wetlands from drainage, filling, or disruption of the surrounding terrestrial habitat. This is especially true for isolated or temporary aquatic habitats. Protection of an ample terrestrial buffer (at least a few hundred meters), ideally including broad habitat connections between disjunct wetlands, is necessary because chicken turtles are known to travel overland between aquatic habitats; as well as, to aestivate and lay eggs on land (Buhlmann and Gibbons 2001). Additional studies should be conducted to identify terrestrial movement patterns and to measure the distance of nests and aestivation sites from water.
In states inhabited only by peripheral populations (e.g., Arkansas, Missouri, Virginia), surveys should be continued or initiated to identify potential protection for all known sites inhabited by the species. Additional specific regional regulations protecting chicken turtles do not seem to be necessary at this time, beyond protection of temporary aquatic habitats.

Captive Husbandry. - The chicken turtle does well in captivity if provided an ample supply of fresh water, sun (or suitable ultraviolet source), and food. Water should be at least one foot deep for adult turtles, with a tapering shoreline or access to readily mounted basking sites. Captives take live crayfish and other aquatic organisms, and some adapt to diets of frozen fish and commercial fish chow. Jackson (unpubl.data) has observed the establishment by adult males of a social hierarchy when several were kept in confined quarters, with the lower ranking males being denied access to favored areas or foods. Therefore, any quarters housing more than one adult male must be sufficiently large or complex to allow animals to roam in visual exclusion from each other. Hatchlings feed readily on small mealworms, and some can be induced to take artificial turtle or fish chow.

If captive reproduction is a goal, females must be provided access to a sandy bank or other appropriate nesting medium.Alternatively, egg laying (once the presence of eggs is determined by palpation or from X-rays) can be successfully induced by injection of oxytocin. On occasion, fertile eggs can be incubated successfully following standard procedures (e.g., ca. $27-29^{\circ} \mathrm{C}$ in moist vermiculite), but at least one study (Jackson 1988) showed a higher rate of hatching when eggs were first exposed to a cool period $\left(15-20^{\circ} \mathrm{C}\right)$ to simulate winter soil temperatures that are commonly endured by eggs in natural nests. Ewert (1985) suggested that a mandatory diapause period may be required between egg laying and hatching. In most situations, eggs that do not experience a cool period will not develop (Ewert et al. 2006)

Current Research. - The most extensive current research on chicken turtles is the continuation of the longterm turtle population surveys begun in 1967 at SRS in South Carolina. Investigators at Savannah River Ecology Laboratory have marked more than 1600 chicken turtles at SRS, and more than 2000 field recaptures have been made. The marked populations of chicken turtles are sampled for determination of individual growth rates, movement patterns, and survivorship. Research to determine movement patterns, nesting behavior, and reproductive output in this species is also planned or in progress for SRS populations.

Acknowledgments. - We thank the following for providing status information: Alvin Braswell (North Carolina), Tom Johnson (Missouri), Stan Trauth and Mike Plummer (Arkansas), Leslie True and Steve Roble (Virginia), and Jennifer Deaton (all states). Manuscript preparation was aided by Contract DE-AC09-76SROO-819 between the U.S. Department of Energy and the University of Georgia's Savannah River Ecology Laboratory. Judy Greene, Tracy Lynch, and Jeff Lovich provided comments on the complete manuscript. 


\section{LITERATURE CITED}

Agassiz, L. 1857. Contributions to the Natural History of the United States of America, Vol. 1, 2. Little, Brown and Company, Boston, MA, $452 \mathrm{pp}$.

Anderson, P. 1965. The Reptiles of Missouri. University of Missouri Press, Columbia, MO, $330 \mathrm{pp}$.

BAUR, G. 1890. The relationship of the genus Dirochelys. American Naturalist 23:1099-1100.

Bennett, D.H., GibBons, J.W., and Franson, J.C. 1970. Terrestrial activity in aquatic turtles. Ecology 51:738-740.

BEYER,G.E.1900.Louisianaherpetology.Proceedings of the Louisiana Society of Naturalists 1897-1899:24-46.

Bonaparte, C.L. 1831. Sulla seconda edizione del Regno Animale del Barone Cuvier osservazioni. Leopoldus Arch., Pagani, 144 pp.

BRASWELL, A.L. 1988. A survey of the amphibians and reptiles of Nags Head Woods Ecological Preserve. ASB Bulletin 35:199-217.

BuHLMAnN, K.A. 1995. Habitat use, terrestrial movements, and conservation of the turtle, Deirochelys reticularia in Virginia. Journal of Herpetology 29:173-181.

BUHLMANN,K.A. 1998.Ecology, terrestrial habitatuse, and conservation of a freshwater turtle assemblage inhabiting a seasonally fluctuating wetland with emphasis on the life history of Deirochelys reticularia. $\mathrm{Ph} . D$. Dissertation, University of Georgia, Athens

BuHLMAnN, K.A. AND GiBBons, J.W. 2001. Terrestrial habitat use by aquatic turtles from a seasonally fluctuating wetland: implications for wetland conservation boundaries. Chelonian Conservation and Biology 4:115-127.

Buhlmann, K.A. AND Johnson, T.R. 1995. Deirochelys reticularia miaria. Herpetological Review 26:209.

Buhlmann, K.A., Lynch, T.K., GibBons, J.W., and Greene, J.L. 1995. Prolonged egg retention in the turtle Deirochelys reticularia in South Carolina. Herpetologica 51:457-462.

BURKE,V.J.AND GIBBONS,J.W.1995.Terrestrial bufferzones and wetland conservation: a case study of freshwater turtles in a Carolina bay. Conservation Biology 9:1365-1369.

ConGDON,J.D. AND GiBBONS,J.W. 1985.Egg components and reproductive characteristics of turtles:relationshipstobody size.Herpetologica 41:194-205.

Congdon, J.D., GibBons, J.W., And Greene, J.L. 1983. Parental investment in the chicken turtle (Deirochelys reticularia). Ecology 64:419-425.

Congdon, J.D., Greene, J.L., AND GibBons, J.W. 1986. Biomass of freshwater turtles: A geographic comparison. American Midland Naturalist 115:165-173.

Cope,E.D. 1875.Check-list of North American Batrachia and Reptilia. Bulletin of the U.S. National Museum 1:1-104.

DAudIN, F.M. 1801. Histoire Naturelle, Generale et Particuliere, des Reptiles. Tome Second. Paris: Dufart, 432 pp.

Demuth, J.P. And BuHLmann, K.A. 1997. Diet of the turtle Deirochelys reticularia on the Savannah River Site, South Carolina. Journal of Herpetology 31:450-453.

Enge, K.M. 1991. Herptile exploitation. Annual performance report, Florida Game and Fresh Water Fish Commission of Tallahassee, FL, $45 \mathrm{pp}$.

ERNST,C.H.AND BARBOUR,R.W.1989.Turtles of the World.Smithsonian Institution Press, Washington, D.C., 313 pp.

EwERT, M.A. 1985. Embryology of turtles. In: Gans, C. (Ed.) Biology of the Reptilia. Academic Press, N.Y., pp. 75-267.

EwERT, M.A. AND Nelson, C.E. 1991. Sex determination in turtles: Diverse patterns and some possible adaptive values. Copeia 1991:50-69.

EwERT, M.A., JACKSON, D.R., AND BuHLMANN, K.A. 2006. Deirochelys reticularia - chicken turtle. In: Meylan, P. (Ed.). Biology and Conservation of Florida Turtles. Chelonian Research Monographs No. 3, pp. 249-259.

GibBons, J.W. 1969. Ecology and population dynamics of the chicken turtle, Deirochelys reticularia. Copeia 1969:669-676.
GiBBons, J.W. 1970. Terrestrial activity and the population dynamics of aquatic turtles. American Midland Naturalist 83:404-414.

GibBons, J.W. 1987. Why do turtles live so long? BioScience 37:262-269.

GibBons, J.W. 1990. Sex ratios and their significance among turtle populations. In: Gibbons, J.W. (Ed.). Life history and Ecology of the Slider Turtle. Smithsonian Institution Press, Washington, DC, pp. 171-182.

GiBBONS, J.W. AND GREENE, J.L. 1978. Selected aspects of the ecology of the chicken turtle, Deirochelys reticularia (Latreille) (Reptilia, Testudines, Emydidae). Journal of Herpetology 12:237-241.

GiBBONs,J.W. ANDLOVICH,J.E. 1990. Sexual dimorphism in turtles with emphasis on the slider turtle (Trachemys scripta). Herpetological Monographs 4:1-29.

GibBons, J.W. AND Nelson, D.H. 1978. The evolutionary significance of delayed emergence from the nest by hatchling turtles. Evolution 32:297-303.

GibBons, J.W., GreENE, J.L., ANd PAtTERson, K.K. 1982. Variation in reproductive characteristics of aquatic turtles. Copeia 1982:776-784.

GraY, J.E. 1870. Supplement to the Catalogue of Shield Reptiles in the Collection of the British Museum.Part I. Testudinata (Tortoises). London: British Museum, 120 pp.

JACKSON, D.R. 1978. Evolution and fossil record of the chicken turtle Deirochelys, with a re-evaluation of the genus. Tulane Studies in Zoology and Botany 20:35-55.

JACKSON, D.R. 1988. Reproductive strategies of sympatric freshwater emydid turtles in northern peninsular Florida. Bulletin of the Florida State Museum, Biological Science 33:113-158.

JACKSON, D.R. 1996. Meat on the move: diet of a predatory turtle, Deirochelys reticularia (Testudines: Emydidae).ChelonianConservation and Biology 2:105-108.

LATREILLE,P.A. 1801. Histoire Naturelle des Reptiles. In: Sonnini, C.S. and Latreille,P.A.Histoire Naturelle des Reptiles, avec figures dessinées d'après nature. Tome Premier. Première Partie. Quadrupèdes et Bipèdes Ovipares. Paris: Deterville, pp. 280.

LoDING,H.P.1922.Apreliminary catalogue of Alabamaamphibians and reptiles. Alabama Museum of Natural History (Geological Survey of Alabama). Museum Paper 5:1-59.

LOVICH, J.E. AND ERNST, C.H. 1989. Variation in the plastral formulae of selected turtles with comments on taxonomic utility. Copeia 1989:304-318.

Mitchell, J.C. and Buhlmann, K.A. 1991. Eastern chicken turtle Deirochelys reticularia reticularia (Latreille). In: Terwilliger, K. (Ed.). Virginia's Endangered Species. McDonald and Woodward Publishing Company, Blacksburg, VA, pp. 459-461.

SchwARTZ, A. 1956. Geographic variation in the chicken turtle Deirochelys reticularia Latreille. Fieldiana (Zoology) 34:461-503.

SchWEIGGER, A.F. 1814. Prodromi monographie cheloniorum. Regiomonti, $58 \mathrm{pp}$.

SeIDEL, M.E. AND AdKINs, M.D. 1989. Variation in turtle myoglobins (subfamily Emydinae:Testudines) examined by isoelectric focusing. Comparative Biochemistry and Physiology 94B:569-573.

STRAUCH,A. 1862.Chelonologische studien, mit besonderer beziehung auf die Schildkrötensammlung der kaiserlichen Akademie der Wissenschaften zu St. Petersburg. Mémoires de l'Académie Impériale des Sciences de St.-Pétersbourg (7)5(7):1-196.

\section{Citation Format for this Account:}

Buhlmann, K.A., GibBons, J.W., and Jackson, D.R. 2008. Deirochelys reticularia (Latreille 1801) - chicken turtle. In: Rhodin, A.G.J., Pritchard, P.C.H., van Dijk, P.P., Saumure, R.A., Buhlmann, K.A., and Iverson, J.B. (Eds.). Conservation Biology of Freshwater Turtles and Tortoises: A Compilation Project of the IUCN/SSC Tortoise and Freshwater Turtle Specialist Group. Chelonian Research Monographs No. 5, pp. 014.1-014.6, doi:10.3854/ crm.5.014.reticularia.v1.2008, http://www.iucn-tftsg.org/cbftt/. 